\title{
BETWEEN NATION-STATE AND THE WORLD- SYSTEM: RUDOLF BIĆANIĆ ON THE TRANSITION TO CAPITALISM IN CROATIA
}

\begin{abstract}
This chapter examines Rudolf Bicanićs interpretation of the transition to capitalism in Croatia. I argue that Bicanic's account is problematic due to a stagist argument and stress on foreign agency in stifling Croatian development. This argumentation neglects the limitations on development imposed by social property relations. I conclude that a more satisfactory account of the transition and its aftermath could be achieved by bringing to bear world-systems analysis and uneven and combined development on the Croatian case.
\end{abstract}

Key words: feudalism, capitalism, manufacture, social property relations, world-systems analysis, uneven and combined development, Croatia

\section{Introduction}

\begin{abstract}
Cical onsidering the recent revival of interest in one of the most important subjects of historical materialism - namely the transition to capitalism ${ }^{1}$ - it seems appropriate to place under scrutiny the work of a scholar who made one of the most lasting contributions to this problematic in Croatia: Rudolf Bićanić. Bićanić is one of the rare scholars for whom the theoretical framework was more than a perfunctory gesture and who attempted to base his interpretation of the emergence of capitalism on fresh advances in Western Marxism. For Bićanić, the most recent influence at the time was Maurice Dobb, who had finished his Studies in the Development of Capitalism in 1946, just a few years before Bićanić's account of the transition to capitalism in Croatia in Doba manufakture u Hrvatskoj i Slavoniji (Period of Manufacture in Croatia and Slavonia). As Terence Byres argues, Dobb's work was that of synthesis by an economist which was nonetheless a major influence on a generation of outstanding historians as it provided a framework for the problems they wanted to address. ${ }^{2}$ Bićanić's intervention is similar: an account of the transition to capitalism written by a political economist. However, the number of sources used in Bićanićs account is not below many a work of history. Furthermore, the staying power of his interpretation of the transition is much greater than that of Dobb, whose work on the rise of capitalism
\end{abstract}

1 Alexander Anievas - Kerem Nişancioğlu, How the West Came to Rule: The Geopolitical Origins of Capitalism, London 2015. See the most recent symposium on How the West Came to Rule in Historical Materialism, 23, 3, 2018.

2 Terence J. Byres, "Rodney Hilton (1916-2002): In Memoriam", Journal of Agrarian Change, 6/1, 2005, 3-4, https://doi.org/10.1111/j.1471-0366.2006.00113.x.

3 Vladimir Stipetić, Dva stoljeća razvoja hrvatskoga gospodarstva (1820.-2005.) [Two Centuries of Croatian Economic Development (1820-2005)], Zagreb 2012. 
was supplanted by later contributors to the debate. In the case of Bićanić, one struggles to find a comparable account of the Croatian transition to capitalism almost 70 years after the publication of the Period of Manufacture. This problematic has been altogether abandoned in Vladimir Stipetić's comprehensive economic history of Croatia, written in the vein of quantitative economic history. ${ }^{3}$

In the following, I will first give an overview of Bićanić's interwar writings. They are relevant to the subsequent discussion not only because Bićanić later argued that the transition to capitalism finished only in 1946, ${ }^{4}$ but also because Bićanić employs interpretive strategies that are present in his later interventions written within a Marxist framework. I then engage in a critical examination of Bićanić's writings on the transition. Although Bićanić's contribution to the understanding of this process in Croatia is of great value, I argue that his conception of capitalist development is problematic and inconsistent, leading to contradictions in his account. More specifically, Bićanić does not provide an explanation of the Croatian transition to capitalism due to a stagist argument, lays too great an emphasis on the Austrian tariff policy to explain Croatia's underdevelopment, thus neglecting the limitations on development imposed by social property relations, and provides a contradictory interpretation of economic thought. I argue that some of these arguments have not been overcome greatly due to the reliance of Croatian historiography on modernization theory. I conclude that a more satisfactory account of the transition and its aftermath could be achieved by an engagement with world-systems analysis (WSA) and uneven and combined development (UCD).

\section{Political economy of interwar Yugoslavia}

The Great Depression that undermined Yugoslavia's already difficult economic position left a scar on Bićanić personally since his father had to declare bankruptcy, a course of action he tried to hinder in vain by selling his book collection. A member of the Croatian Peasant Party and a staunch critic of the regime, Bićanić had to face further difficulties. He was stripped of his doctoral title in political economy earned at the Law Faculty in Zagreb and sent to Mitrovica prison for 3 years, the reason being pamphlets written against King Alexander. ${ }^{5}$ The trials of jail were later represented by Bićanić in his Kako živi narod (How the People Live) as an eye-opening experience that exposed all the inadequacies of the Croatian intellectual elite, which, with its eyes fixed on the Western world, was wholly ignorant of the experience of the largest majority of their own fellow Croats - the peasants:

Our gentlemen know more about cultural developments of Vienna and Paris than about cultural developments in Čučerje and Posavski Bregi situated ten kilometers from Zagreb. They know more about political ideologies of the English and Germans

4 Rudolf Bićanić, "Ekonomska podloga događaja 1903. u Hrvatskoj" ["Economic Base of 1903 Events in Croatia"], in: Economic Base and Other Works, eds. Ivo Bićanić - Uroš Dujšin, Zagreb 1995, 292.

5 Michael Kaser, "Preface”, in: Bićanić, Economic Policy of Socialist Yugoslavia, Cambridge 1973, VII; Uroš Dujšin, „Prof. dr. Rudolf Bićanić, 1905-1968“, in: Bićanić, Ekonomska podloga hrvatskog pitanja i drugi radovi [Economic Base and Other Works], eds. Ivo Bićanić - Uroš Dujšin, Zagreb 1995, 500. 
than they are familiar with the thoughts of the Croatian peasant regarding the state and economic order. They deal with the economic problems of the Far East, rather than to inquire how and from what activity do the peasant and the worker in the nearest surrounding live from. Even then, when it is most nationalist, our intelligentsia is so only formally, in principle, but not in reality. When it is most social, it is so in doctrines and abstractions. Not only that little is known about real life of the people, but very often wrong conceptions of it arise. It is painted in a manner as it used to be, or how someone prefers to paint it, and not as it really is. ${ }^{6}$

In order to demonstrate to the reader how life in the village "really is", Bićanić engaged in a substantial amount of travel, mostly carried out on foot, across the Croatian countryside. The reader is reminded of his privileged epistemological position as a direct observer who gathered most of his data by interaction with villagers. But empirical observation is not enough. Bićanić also asserts his superior interpretative framework. Since peasant culture serves the intellectuals as an aesthetic object, transformations of rural life are sought within the cultural register. What is missing is the recognition that rural life is a social phenomenon that needs to be related to the society as a whole. This perspective shields Bićanić from the "fantasies" of ethnographic research. ${ }^{7}$ But there was more. Research represented in the book was only conceivable due to the fact that the peasants could confide in Bićanić, which is made possible when the peasants "realize and feel that you are one of them, completely theirs." After this bond is established, the identity of the observer is, of course, immediately transformed as well. He cannot but "feel their troubles as his own, and their struggle as his own. He cannot but become one with them." ${ }^{8}$

What analysis did this shift in epistemology bring about? Bićanić put forward the argument that the reason for the dire straits of the peasantry lied in the exploitation inherent in the capitalist mode of production, a system that is incapable of solving the peasant question. ${ }^{9}$ It only increased the exploitation of the peasantry. ${ }^{10}$ The often disparaged "gentlemen" are represented as "servants" of the West, extracting the resources of their society to the benefit of their Western overlords. ${ }^{11}$ Within the country the local merchant class is taken to task as the most exploitative class, a feature considered characteristic for early capitalist development. These merchants usually control the local banks, which, rather than furthering the development of agricultural productivity via cheaper credits, have only strengthened the hold of merchant capital over the peasantry. ${ }^{12}$ These developments are most acutely felt in the so-called "passive areas" ("pasivni krajevi") - Lika, Dalmatian hinterland, western Hercegovina - that take center stage in How the People Live. The greater the backwardness, the greater, ironically, argued

6 Bićanić, Kako živi narod: život u pasivnim krajevima [How the People Live: Life in Passive Regions], 1, Zagreb 1936, 4. All translations, if not otherwise indicated, are mine.

7 Ibid., 5, 96.

8 Ibid., 8.

9 Ibid., 38.

10 Ibid., 19.

11 Ibid., 125-126.

12 Ibid., 79-83. 
Bićanić, the dependence on the market. ${ }^{13}$ Landlords are not forgotten either. Trapped in their "feudal understanding", they cannot see that the wages given to rural labor are insufficient for costs of life. ${ }^{14}$

To reverse this course of events, Bićanić argues for peasant autarchy. Breaking ties with the world market is one of the first steps to be taken. ${ }^{15}$ Proletarianization of the peasantry should be blocked by abolishing foreclosures on peasant property, and peasant zadruga - communal organization already present in precapitalist times - is evoked several times throughout the text as a solution to peasant woes. ${ }^{16}$ This results in substantial frictions in the text. Bićanić himself ridicules "romantics" who cannot grasp why the peasants are leaving this form of association. He tries to overcome this contradiction by arguing that zadruga will receive a new lease of life after a certain level of development is reached. This traditional organization is to be revived under more advanced socioeconomic relations as, once more, the most viable organizational form for the peasants. This is exactly why zadrugarstvo is strongest in more developed parts of Croatia. The same process can thus only repeat itself in passive areas, with the beneficial assistance of the Croatian Peasant Party, which is seen as crucial in "awakening" the consciousness of the peasantry in passive areas, a catalyzer in a natural process. ${ }^{17}$

While the life of the peasantry lay at the forefront of How the People Live, it was accorded a more marginal position in Ekonomska podloga hrvatskog pitanja (The Economic Base of the Croatian Question), a work whose first edition was confiscated and the second published and prefaced by Vladko Maček, the leader of the Peasant Party negotiating with Belgrade on creating an autonomous Croatian unit within Yugoslavia. ${ }^{18}$ The insights of a quasi-anthropologist are here replaced with the perspective of a political economist, statistics rather than people's experiences being the main source of reference. Bićanić argued that the political economy of Yugoslavia was tilted foremost against its most developed parts (Croatia, Slovenia, Vojvodina). But neither were all the underdeveloped areas spared, with Macedonians especially enduring extreme hardship. The entire Yugoslavia was subservient to the interests of "Srbijanci", the population of Serbia. Furthermore, within Serbia itself, the parasitic elite tied to the oppressive state apparatus enjoys a significant increase of in wealth with no concern for their own countrymen. ${ }^{19}$

Even though the title refers to Croats, the text appeals to a wider audience. Internally, the coalition between Croatian Serbs and the Peasant Party demanded this, while on the level of Yugoslavia it is stated that a natural alliance should be formed amongst the most developed areas. ${ }^{20}$ But it is up to Croatia to change the existing relations for the better. Enjoying the patronage of civilized Habsburg rule, granted substantial autonomy within

13 Ibid., 79-80.

14 Isti, Kako živi narod: život u pasivnim krajevima [How the People Live: Life in the Passive Regions], 2, Zagreb 1939, 18.

15 Isti, Kako živi narod, 1, 50, 72.

16 Ibid., 20, 54, 87-88.

17 Ibid., 106, 109, 120.

18 Dujšin, "Prof. dr. Rudolf Bićanić", 500-501.

19 Bićanić, "Ekonomska podloga hrvatskog pitanja", 7-9.

20 Ibid., 13. 
Hungary, achieving a respectable level of development, Croats were shocked by the primitive environment they were forced to suffer under in Yugoslavia. Robbed of its former autonomy, reins of power concentrated in Belgrade with no representatives of Croatian interests, save for a few token Croats, its nationality negated, forced to pay for the debts and development of Serbia under the banner of national unity while its own population in underdeveloped areas received no aid to speak of, humiliated by the Serbian-dominated state apparatus, Croatia was almost reduced to a colony of Serbian imperialism. ${ }^{21}$ But it is an inverse colonialism, for the most developed are exploited by the less developed ones via the state apparatus, which Bićanić characterizes as:

One colossal, inert, lazy, indifferent, desperately formalistic, slow to react, unpractical, irrational and ignorant, and yet terribly expensive bureaucratic apparatus with Oriental traditions, methods and morality, that can only be put in motion with "grease", which is sustained by personal protections or suffers from personal and party vengeance, and which holds in its hands the whole of power from the largest state businesses, works and contracts, to the most petty corruption of hiring and transferring state employees or issuing craft permits...22

Continuing in the Orientalist idiom, Bićanić argued that the primitive "Balkan-Levantine" machinery was being transformed into a more efficient vehicle for exploitation after the dictatorship was introduced in 1929, thus presenting an even a greater danger for Croatia. ${ }^{23}$ Political and economic autonomy is the only exit out of this predicament. Yugoslavia has to be reshaped in a new federalist mold. In this context, comparisons with the Habsburg Monarchy return. Unsatisfying as it was for Croats, the autonomy enjoyed under dualism is used as a vantage point from which to reconsider political relations within Yugoslavia. ${ }^{24}$ While Serbian imperialism will surely resists this change since its main aim is to change economic relations to the benefit of Serbia by relying on unequal power in politics, a reorganization of the system is still inevitable. This is so, Bićanić argued, because Serbian imperialism does not have a sufficiently large economic base. It is at this moment that the peasant returns. The system will break when it lays its parasitic hands on this lifeblood of the economy. Then a point of no return will be reached, with unpredictable consequences. ${ }^{25}$

\section{Transition to capitalism in the Habsburg Monarchy}

His post-war writings were written in a different register and framework, but, as we shall see, some arguments employed in the interwar were retained. After a stint as the representative of Yugoslavia at UNRRA, where he secured substantial aid, ${ }^{26}$ Bićanić turned

21 Ibid., 23-38, 67-68, 103.

22 Ibid., 82.

23 Ibid., 54, 203.

24 Ibid., 210-211.

25 Ibid., 213, 217.

26 Dujšin, "Prof. dr. Rudolf Bićanić", 501. 
to a university career. Considering the fundamentally different political circumstances, it is not surprising that Bićanić's first major postwar contributions were within the discourse of history, far removed from the politically charged works of the interwar. At the time a debate on the origins of capitalism was springing up in Western Marxism, a problematic that tied in well with Bićanićs interwar writings and, in a more mediated fashion, with his political ideology in which the scorn of "gentlemen" and "servants" of the West was commonplace while sympathies were reserved for the exploited. His stay in Britain as a representative of the Peasant Party at the government in exile helped him to familiarize himself with Dobb's major contribution. Engagement with Marxism resulted in a more developed account of capitalism and to the abandonment of elements of agrarian utopianism of his earlier writings. This is especially evident vis-à-vis the zadruga, which is relegated to a stagnant non-capitalist sector slowly incorporated by the growing capitalist one. ${ }^{27}$ But Marxists texts that Bićanić relied on were not fully absorbed, which resulted in a conceptualization of the transition to capitalism that was inconsistent.

The difficulties involved with the assimilation of Marxist texts were perhaps compounded by his partial reliance on Dobb's Studies on the Development of Capitalism. The great advantage of this account was the demonstration of the limitations of a perspective focused on trade as the solvent of capitalism. For Dobb, this meant abstracting away the specific relations of production of feudalism that determined the type of reaction to different trends in trade available to the social classes of feudalism. Growth of trade, which is not inimical to feudalism, could not in itself dissolve feudalism as it did not entail changed relations of production. And change in the relations of production could come from a direct clash between a class of capitalist producers and feudal lords. ${ }^{28}$ Several problems with Dobb's argument that Robert Brenner brings to the fore are worth considering. As Brenner points out, Dobb seems to vacillate between the limiting effects of relations of production and the ability of productive forces to develop under them. Dobb's interpretation is contradictory in this sense because he sees feudalism as essentially dead at the end of the late medieval crisis but still argues that the revolution was necessary in mid$17^{\text {th }}$ century to overthrow it. However, his own dates suggest that it was capitalism rather than feudalism that was responsible for the development of the productive forces. Aside from this problematic causality, Dobb also uses a version of class essentialism whereby petty commodity producers develop productive forces while landlords hinder them, not taking into account the possibility that the nature of relations of production simply forced landlords to adapt to the rigors of the market. Dobb's account also seems to exhibit mild signs of economic reductionism and determinism when he suggests that the capacities of the feudal lords to engage in class struggle should be secondary to the consideration of economic factors when examining the transition to capitalism. This is problematic for two reasons. One is that it is hard to find more important factors than the capacity of the lords and feudal states to wage class warfare for the maintenance of feudal relations of production. The second is that the nature of surplus extraction was extra-economic and any separation between politics and economics, also problematic in capitalist societies

27 Bićanić, Doba manufakture u Hrvatskoj i Slavoniji (1750-1860) [Period of Manufacture in Croatia and Slavonia (1750-1860)], Zagreb 1951, 38-39; Isti, "Ekonomska podloga događaja 1903.", 294-295.

28 Maurice Herbert Dobb, Studies in the Development of Capitalism, Rev. ed., New York 1963. 
where there is a separation between the two, is particularly debilitating when analyzing pre-capitalist modes of production. ${ }^{29}$ Brenner seems to downplay another aspect of Dobb's interpretation, and that is, despite continuous reservation on the issue, that trade and towns are an important part of the story of transition. ${ }^{30}$ It is a very difficult operation, even putting aside the contradictions in Dobb's argument, to provide an account of the transition where relations of production in agriculture are coupled with a discussion of trade in a unified perspective.

Bićanić further muddied the waters by an overly strong commitment to stagism and a definition of capitalism that appears incompatible with the advances made by Dobb. None other than the Great Dialectician Joseph Stalin is quoted to explain why societies transitioned to capitalism: "Why was it that capitalism smashed and destroyed feudalism? Because it created higher standards of productivity of labor, it enabled society to procure an incomparably higher quantity of products than could be procured under the feudal system, because it made society richer." ${ }^{\prime \prime 1}$ Astonishingly, Bićanić decided to simply ignore a rich discussion of the transition to capitalism in Studies in the Development of Capitalism - indeed the main theses of the book are never discussed - and instead chose Stalin's casual remark on the issue. ${ }^{32}$ Bićanić then invokes Marx, Lenin and Dobb to introduce manufacture as a specific period in the development of capitalism. Bićanić argues that manufacture is a transitional form of production between handicrafts characteristic of feudalism and the machinery characteristic of industrial capitalism. Aside from being a period in the development of capitalism, Bićanić considered it also distinguished by the fact that feudalism is dominant and capitalism is emerging, and that manufacture is dominant over other modes of capitalist production. ${ }^{33}$ However, although manufacture is undermining the existing mode of production, the productivity in manufacture is still insufficient to overcome it. In a paradoxical formulation, although "crushing" the feudal relations of production, manufacture was in no position to change them. This was the task of the industrial production. ${ }^{34}$

Further conceptual difficulties are brought in with a definition of capitalism that does not contain any reference to relations of production. Feudalism is defined as a "sum" of economic units which are operating in conditions of a natural economy. Capitalism on the other hand is a "system of economic units, connected via the process of social production, i. e. territorial division of labor. In it, the single unit depends on the other, and so they exchange their products on the market." ${ }^{\prime 35}$ Manufacture plays a key role in furthering the development of this social production, leading to the formation of a national market. ${ }^{36} \mathrm{Al}-$

29 Robert Brenner, "Dobb on the Transition from Feudalism to Capitalism", Cambridge Journal of Economics, 2, 1978, 122, 124, 126, 128, 136.

30 Dobb, Studies in the Development of Capitalism, chap. 2.

31 Joseph V. Stalin, Problems of Leninism, Moscow 1954, 664; Bićanić, Doba manufakture, 1.

32 This is perhaps explicable by a strategy of ideological mimicry. However, stagism characteristic of Stalinism had a profound impact on Bićanić's account of the transition.

33 Bićanić, Doba manufakture, 2.

34 Ibid., 3.

35 Ibid., 10-11

36 Ibid., 11, 179. 
though implicitly linking social division of labor with the division of labor within economic units, these potential connections are not discussed while relations of production under feudalism are ignored. But for Marx, the formation of the national market is based on the dialectics between social division of labor and the economic units that continually cut costs as a result of competitive accumulation based on wage labor. Indeed, the division of labor in manufacture is to Marx a consequence of an already achieved division of labor. ${ }^{37}$ Manufacture is naturally benefiting from the creation of the world market and the colonial system, processes forming a part of primitive accumulation. But a crucial aspect of primitive accumulation was the formation of wage labor, ${ }^{38}$ a point that Dobb refers to as well. ${ }^{39}$ Without it, capitalist production cannot take place. Bićanić appears to have ignored these aspects of Marx's argument. They would seem to pose the question of how manufacture potentially led to different results in areas that did not have capitalist relations of production as its development was hindered by different social property relations. Bićanić undermines his conceptualization of manufacture when he argues that manufacture was a dominant form of capitalist production in $17^{\text {th }}$ century England, which already had capitalist relations of production. ${ }^{40}$ This argument is also at odds with the one that it was the industrial revolution which had to introduce capitalism. How so when England was capitalist before it?

However, relative marginalization of Marx's original arguments, some of which turned out to be incorrect, is certainly no guarantee that an interpretation of the transition should be wrong. Let us see if the analysis of the political economy of Croatia corresponds to the theoretical framework introduced to sustain Bićanić's argument. The expected results of the period of manufacture could be summarized as follows. The transition to capitalism should have followed the path of ever greater dominance of manufacture, which brought in ever more labor from the feudal sector and generated ever greater demand. A whole new capitalist system emerged alongside feudalism and when sufficiently developed, as expressed in the existence of a national market of interconnected economic units, it overthrew feudalism and replaced it with relations of production more conducive to the development of productive forces, potentially in a revolution led by the national bourgeoisie.

Yet there is barely a trace of these developments in Bićanić's account of the Croatian transition to capitalism. Almost at the very outset, Bićanić states that manufacture was merely a "baroque façade" consisting of "the refinery of colonial sugar, silk production and the making of oak staves for the export of French wine". Behind this facade lay the reality of feudalism and serfdom. ${ }^{41}$ Such a major discrepancy between the conception of capitalist development and the reality of Croatian political economy required an explanation as to why capitalism was incapable of bringing about social change in line with Bićanić's conception of capitalist development.

One strategy Bićanić employs to account for this deviation from the supposedly natural path of development is to introduce an external agency that prevented capitalism from flourishing in Croatia. That external agency is Austrian absolutism. From the benevolent

\footnotetext{
37 Karl Marx, Capital: A Critique of Political Economy, 1, London 1990, 480, 473.

38 Ibid., 875.

39 Dobb, Studies in the Development of Capitalism, 223.

40 Bićanić, Doba manufakture, 3.

41 Ibid., 4.
} 
rulers of the interwar writings, Habsburgs now bear the brunt of criticism for Croatia's underdevelopment. Through their customs policy they have reduced both Hungary and Croatia to "colonies". ${ }^{42}$ Although the local nobility was not in the position to pay taxes as it presided over a social formation at a lower level of development than regions in Austria, this mattered little to Habsburgs who imposed a higher tariff on Croatian and Hungarian agricultural products to compensate for the unwillingness of the local nobility to pay taxes. Perhaps more importantly, they had introduced even higher tariffs on the exports of manufactured products from Hungary and Croatia to the western parts of the monarchy, substantially hindering development of manufacturing. ${ }^{43}$ Bićanić went as far as to state that the development of Rijeka, a free port with a solid manufacturing base, shows well how Austrian tariffs were "suffocating" similar developments in the rest of Croatia. ${ }^{44}$ Local agencies are taken to task as well, in an echo of the interwar critique of Croatian political economy. Capitalists were incompetent, leaving the exploitation of forests to foreign capital, in relation to which they played a "second- and third-class role". ${ }^{45}$ Even though some gained a level of independence, local merchants were essentially agents of foreign firms. Unable to comprehend the changing times, they were swept away in the period of industrial revolution. ${ }^{46}$ The landlords receive a treatment that seems to cover the entire gamut of possible arguments. At times, they are engaging in capitalist production simply by the virtue of participating in "world competition", even though the estates of Croatian nobles are not productive enough to withstand the pressure of other peripheral producers (Egypt, Russia, Romanian Principalities). ${ }^{47}$ They sometimes use a "combination" of the organization of labor in manufacture with serf labor. But they are also mere "unnecessary parasites" after the transition to capitalism, using the profits for their own consumption, with only few transitioning to "agrarian industry". ${ }^{48}$ In other places large estates seem synonymous with "feudal organization." 49

Bićanić's argument regarding tariffs hindering development of Croatia and Hungary may seem appealing to many, from $19^{\text {th }}$ century actors such as Kossuth to Hungarian and Croatian historians, but it is an argument that appears less convincing when placed under closer scrutiny. For when it comes to taxation, Croatia and Hungary were at the very bottom of the table in the Habsburg Monarchy..$^{50}$ The damage these areas incurred from tariffs still left them with more than enough to spare. Even if we would make the absurd assumption that all the tariff payments in 1847, when the volume of trade was much greater than in the former decade and the damage incurred was therefore greater too, were paid by Croatia and Hungary, they would still have been left with millions of $\mathrm{f}$.

42 Ibid., 191, 231.

43 Ibid., 196-203.

44 Ibid., 225.

45 Ibid., 227.

46 Ibid., 119, 349-350; Isti, "Ekonomska podloga događaja 1903.", 227.

47 Isti, Počeci kapitalizma u hrvatskoj ekonomici i politici [The Beginnings of Capitalism in Croatian Economy and Politics], Zagreb 1952, 71-73, 79-80.

48 Isti, Doba manufakture, 248.

49 Ibid., 292.

50 Harm-Hinrich Brandt, Der österreichische Neoabsolutismus: Staatsfinanzen und Politik 1848-1860, 2, Göttingen 1978, 1083. 
more than in the case that they had had to pay taxes on the level of the less developed members of the Austrian customs union. ${ }^{51}$ The fact that the exporters paid a mild tariff pales in comparison with the massive advantages enjoyed under the system of very low taxation in general and no taxation at all for the nobles and aristocrats who exported their goods to the Austrian part of the Monarchy. This is even more so for narrow Croatia (comprising three counties in northern Croatia and excluding Slavonia), which enjoyed a reduced tax rate in the Hungarian Kingdom. ${ }^{52}$

The problematic nature of the argument that the tariff system was a major factor in the underdevelopment of Croatia becomes even more evident when we compare Croatia and Hungary with areas with very similar social property relations whose exports were not hindered by tariffs. In Poland, the late medieval grain boom led to the greater use of extra-economic coercion as the nobility responded to increased market opportunities. The strengthening of serfdom resulted in disastrous consequences for Poland's development. Greater extraction of surpluses from the peasantry weakened the internal market, while the availability of unpaid labor hindered innovations in agriculture. Tying the peasantry to the land undermined the development of the cities and reduced the supply of labor. Although Poland's ruling class did naturally not introduce a tariff on its own exports, the manner of surplus extraction was so debilitating on development that the Polish landowners found it hard to respond to later increases in demand. ${ }^{53}$ Then there are the Romanian Principalities that gained access to the word market after the Treaty of Adrianople in 1829. As in Poland, the export to the world market led to increased use of extra-economic coercion. Here again the lack of tariffs did not prevent the Principalities from achieving a rather abysmal developmental record. ${ }^{54}$

Fundamentally different developmental trajectories of (semi)peripheries that had capitalist social property relations provide additional support to the argument that social property relations have to be considered as important when discussing uneven development under capitalism when extra-economic coercion prevailed in many regions of the capitalist world-system. We may take the example of two (semi)peripheries that moved to the core at the time when Croatia and Hungary were being "underdeveloped": the United States and Scotland. The GDP per capita of the then British colonies in America and the part of the Spanish empire that was to become Mexico was not very much apart at the beginning of the $18^{\text {th }}$ century. Hundred years later the US became a far more developed country. ${ }^{55}$ The difference between the future US and Eastern Europe also grew substantially even though both were peripheral producers in the early modern period. What differentiated the United States from Eastern Europe was the "empty" land conquered through massacre on which petty commodity production was established. By the period of our interest, mid-19 $9^{\text {th }}$

51 Joseph Hain, Handbuch der Statistik des österreichischen Kaiserstaates, 2, Vienna 1853, 512-513.

52 János Varga, A Hungarian Quo Vadis: Political Trends and Theories of the Early 1840s, Budapest 1993, 91.

53 Brenner, "The Origins of Capitalist Development: A Critique of Neo-Smithian Marxism", New Left Review, I/104, 1977, 67-70; Robert A. Denemark - Kenneth P. Thomas, "The Brenner-Wallerstein Debate", International Studies Quarterly, 32/1, 1988, 47-65.

54 Perry Anderson, Lineages of the Absolutist State, London 1986, 392.

55 David S. Landes, The Wealth and Poverty of Nations: Why Some Are so Rich and Some so Poor, London 1998, 292. 
century, the United States, excluding the South, was a world apart from Eastern Europe in terms of economic development and would even begin to outcompete the region on the European market, despite enormous distances, as it was by then a fully capitalist economy. It is next to impossible to ignore local relations of production and the development of a robust internal market when discussing the shift of the US to core position. Protectionist policies aided this, but they could only have worked due to the fact that the conditions for their positive effects were already there. This comparison becomes even more telling when we throw a glance at the American South, far and away inferior in terms of productivity growth, with a very weak internal market, trapped in the underdevelopment dictated by a political economy that was detrimental to the long-term prospects of the region. ${ }^{56}$ Scotland also demonstrates how social property relations could have a major impact on a region's developmental prospects. Still in mid- $18^{\text {th }}$ century, Scotland was a relatively backward society. ${ }^{57}$ However, when it was freed from feudal constraints and started to operate as a capitalist economy, it caught up with England as early as the beginning of the $19^{\text {th }}$ century by borrowing the most advanced means of production. ${ }^{58}$ The weight of social property relations is also evident within the Monarchy. Lombardy paid around thirty percent of total agricultural production in taxes, much more than Hungary and Croatia that paid around six times less, but was still far more developed than any region in Hungary. This was so because Lombardy had a developed capitalist agriculture by the end of the $18^{\text {th }}$ century and its more dynamic economy could thus sustain much higher levels of taxation. ${ }^{59}$ The tariffs seem to appear onerous to Croatian historians precisely because of the sheer underdevelopment of Hungary and Croatia.

The contrasting cases of Poland and Romanian Principalities on the one hand and the US, Scotland, and the Italian provinces of the Monarchy on the other, strongly suggest that other factors aside from "colonial" policies might lie behind the (under)development of a region. Thus, although the abolition of the customs toll in the Monarchy would have increased the resources of the landlords, it is hard to argue that those resources would have been used for investment in productive activity that would have led to a convergence in development. Considering the weight of social-property relations on the entire economy, the relative impact would have probably been marginal, barring a complete overhaul of social relations, a course of action the landlords were not willing to embark upon. Core-periphery relations need not always arise due to strategies of underdevelopment pursued by the core so as to further greater capital accumulation in its territory. Social-property relations might be responsible as well as areas with extra-economic coercion integrated into the world market necessarily undergo underdevelopment. This seems to be a major factor determining the development/underdevelopment of an area in the context of a capitalist world-system characterized by the use of extra-economic coercion in the periphery.

56 Charles Post, The American Road to Capitalism: Studies in Class-Structure, Economic Development and Political Conflict, 1620-1877, Haymarket Books, 2012.

57 Neil Davidson, The Origins of Scottish Nationhood, London 2000, 56.

58 Isti, Discovering the Scottish Revolution 1692-1746, London 2003, 275.

59 Dylan Riley, "Privilege and Property: The Political Foundations of Failed Class Formation in Eighteenth-Century Austrian Lombardy", Comparative Studies in Society and History, 45/1, 2003, 194-199, https://doi. org/10.1017/S0010417503000094. 
While neglecting the rather rigid framework social-property relations imposed on the development of Croatia and trying to explain underdevelopment via "colonial policy", Bićanić had somewhat neglected, as virtually all economic historians, an area nominally under the jurisdiction of the Croatian Kingdom yet directly subjected to administration from Austria: the Military Frontier. Although aware of the underdevelopment of the Frontier, Bićanić did not integrate it into a comprehensive account of uneven development in Croatia. Coming into being as a result of a clash between a developed tributary formation of the Ottomans and Austrian absolutism, this peculiar formation where zadrugas were kept alive to provide soldiers for the empire is arguably precisely the area where the underdevelopment is to be attributed to an external agency. Here the zadruga was kept on life support by legal fiat and a complex system of tax breaks, exemptions, and fiscal transfers. The Frontier society was to serve the empire by being deliberately kept in a state of low development as any socioeconomic differentiation would have sounded the death knell of this vast military camp since it would have undermined its social base. The social laws of motion were to an extent "suspended" by the Austrian state to keep the large production units that could provide a surplus of soldiers in place. An institutional setup was created that was geared towards hindering rather than furthering development. Consequently, as Drago Roksandić argues, the Frontier was doomed to be an undeveloped agricultural society and social change had to be exogenous. ${ }^{60}$ Considering that other soldiers drew their wage all the time and the Grenzers were paid only when employed outside the Frontier, the Austrian state extracted, in a mediated fashion, a great amount of resources that could be productively used in other parts of the Monarchy. Taking into account how much cheaper the soldiers from the Frontier were, the troop levels maintained and the average military budget in the Vormärz, the transfer of value seems to be comparable to the entire tax for Croatia, Hungary and Banat. ${ }^{61}$ In the Frontier, it was the interplay between capitalism and geopolitical competition that brought about the coming into being of a society whose backwardness was a direct outcome of state agency. Perhaps because it was so mediated that the transfer of value remained ignored by economic historians. But if one wishes to target Viennese policy, this seems the place to do it.

Be that as it may, Bićanić's account seems seriously undermined by the fact that Austrian tariffs are not sufficient to explain the great differences in development between Croatia and Hungary and more developed areas of the Monarchy. There is, however, another interpretative strategy that Bićanić resorts to and that is to account for the underdevelopment in Croatia by a shift in the characterization of capitalist development:

Capitalism exhibits in Croatia during the period of pre-industrial manufacturing its basic contradiction of expansion of production, and reduction in the expenditure

60 Roksandić, Vojna Hrvatska, 1, 182.

61 Brandt, Der österreichische Neoabsolutismus, 603, 605-606; Carl Bernh - Ritter von Hietzinger, Statistik der Militärgränze des österreichischen Kaiserthums, 2, Vienna 1823, 552; Mirko Valentić, "Osnovni problemi u ekonomici Hrv.-Slav. Krajine od 1850.-1873" ["Basic Problems in the Economy of the Cro.Slav. Frontir 1850-1873"], Historijski zbornik, 17, 1965, 89; Karl Kaser, Freier Bauer und Soldat: Die Militarisierung der agrarischen gesellschaft and der kroatisch-slawonischen Militärgrenze (1535-1881), Wien 1997, 392-393. 
basis. The capitalist mode of production spreads more to the production of iron for exports, rather than on manufacturing scythes, hoes and axes; on exporting staves, and not on making wooden furniture; on export of flour and pasta, while the flour for domestic usage is grinded in village mills. Capital is invested in the production of silk for export, and not in the production of flax and hemp for local consumption. Capitalists produce colonial sugar, and not domestic honey; potash, and not the salt from the sea for home consumers, who suffer from salt shortages. ${ }^{62}$

Bićanić tries to support his argument by a reference to Lenin, who seems to argue for exactly the opposite, stating that capitalism would develop a home market. ${ }^{63}$ Perhaps the transition to industrial production, equated by Bićanić with the capitalist mode of production, would remedy this situation. Yet Bićanić is again forced to state the opposite. Once more, capitalist production serves the foreign market-but now to an even greater extent. ${ }^{64}$ Aside from being a significant departure from the notion of capitalist development introduced at the beginning of The Period of Manufacture, this conception begs the question where those external markets are to be found if this is characteristic of capitalist societies in general. Bićanić thus vacillates between two incompatible versions of capitalist development. They can, however, be reconciled by leaving the confines of the nation-state as the unit of analysis and turning our eyes to the totality of the capitalist world-system. This perspective was already present in Lenin, whom Bićanić heavily relied on. According to Lenin, capitalism was marked by uneven development where the core areas of the world-system dominate the peripheral ones, with an intermediary layer of countries like Russia that could partially emulate the Western societies but not recreate its social structures. By the late $19^{\text {th }}$ century the path to core development was closed off to most countries of the world-system. ${ }^{65}$ This perspective was, of course with some differences in relation to Lenin, developed to new heights in WSA. ${ }^{66}$ In this framework, the core countries correspond well to Bićanić's first definition of capitalism as a mode of production. The peripheral formations correspond to the second. And Croatia was a peripheral social formation.

Bićanić's error was to frame the transition in the language of stages, a perspective that was bound to disappoint. For there were no stages to be reached as a great part of the capitalist world-system was characterized by externally oriented economies which were appendages of the core economies. They were not appendages because of an incomplete transition and the like, but precisely because of the manner of their integration into the capitalist system. In Samir Amin's words, peripheral economies were "disarticulated", characterized by the absence of a feedback loop between sectors generating a robust internal market. ${ }^{67}$ Yet, I have argued that social property relations were a major factor in

62 Bićanić, Doba manufakture, 183.

63 Vladimir I. Lenin, "The Development of Capitalism in Russia", in: Collected Works, 3, 4th ed., Moscow 1977, 37-39, 69.

64 Bićanić, Doba manufakture, 225-226.

65 Davidson, We Cannot Escape History, Chicago 2015, 163-167.

${ }^{66}$ For a short introduction see: Immanuel Wallerstein, World-Systems Analysis: An Introduction, Duke University Press Books, 2004.

67 Samir Amin, L'accumulation à l'échelle mondiale, 1, Paris 1970, 31-42. 
determining the manner of the incorporation into the world-system. There thus appears to be a contradiction between arguing that social property relations explain unevenness and the lack of convergence after their introduction. This is only an apparent contradiction as the later transitions to wage labor could no longer have the same effect since this system of social property relations was being generalized throughout the world-system and because the capitalist mode of production itself generates unevenness in development. Social property relations were important in an earlier distribution of positions in the core-periphery structure but were in no position to overcome it. As Drago Roksandić put it in relation to the Croatian transition to capitalism, the abolition of feudal social property relations was taking place in an already formed core-periphery structure. ${ }^{68}$ The developmental path was thus necessarily different.

Considering these problematic aspects of Bićanić's argument, it is not surprising that he does not explain the actual change to the new mode of production as he cannot find the social forces that led the transition to a new society. Stagism again proves to be a significant obstacle to an adequate interpretation. Bićanić sometimes suggests that there was an increasing share of wage labor and that the process of primitive accumulation was occurring on the land, without weaving these elements into a thesis on transition. ${ }^{69}$ He thought that Croatian nobility was conservative because of small plots, bad land and competition from Hungary and Slavonia. ${ }^{70}$ However, although he notes that the Croatian national movement, as well as Yugoslavism, lacked a material basis and was dominated by weak merchant capital, Bićanić still argues that the Illyrian movement should be seen as an attempt to create a national market. ${ }^{71}$

To support this argument Bićanić needs to show that there was at least a major discussion on overcoming the backwardness of Croatia by a transition to capitalism. Bićanić tries to provide this by a contradictory reading of what is universally considered the most important intervention in the discourse of political economy at the time: Disertacija (Dissertation) of Janko Drašković. Although noting how much Drašković's argument were shaped by the interests of merchant capital and landlords, he still claims that Drašković formulated an industrial policy. ${ }^{72} \mathrm{~A}$ similar assessment of Drašković's work is given by Stipetić in the most comprehensive history of Croatian economic thought where it is argued that Drašković saw industrialization as "a means of economic progress" ${ }^{73}$ By this yardstick István Széchenyi was a protectionist and Lajos Kossuth a communist. Indeed, a comparison with Széchenyi's Hitel (Credit), a bestseller of Hungarian political economy that was potentially a direct influence on Drašković's Dissertation, shows how conservative the text in fact was. For Széchenyi explicitly states, in contrast to Drašković, that the competition of other producers and high tariffs are not the cause of backwardness, but rather the numerous deficiencies of the social system, including the difficulty of raising

68 Roksandić, U Ninu i Danasu [In Nin and Danas], Zagreb 2011, 164.

69 Bićanić, Počeci kapitalizma, 89, 94-95.

70 Isti, Počeci kapitalizma, 120.

71 Isti, Doba manufakture, 11-12.

72 Ibid., 335-336; Isti, Počeci kapitalizma, 147-150.

73 Stipetić, Povijest hrvatske ekonomske misli (1298.-1847.) [History of Croatian Economic Thought (12981847)], Zagreb 2001, 651. 
productivity with serf labor. The developmental path to be followed, in accordance with his Smithianism, would be a strong internal market followed by growing exports. And the main class to blame for the backwardness of the country were the "affluent landowners". ${ }^{74}$ Széchenyi did not accept the implications of some aspects of his analysis and resorted to overemphasis on credit as a solution to developmental problems. He also articulated a meek political agenda. However, many elements of Széchenyi's argument are virtually absent in Drašković, who had little to say regarding the limits on development imposed by feudal social property relations. This is incompatible with the claim that he was a proponent of an industrial policy-the conscious effort to structure economic activity in a manner that will facilitate industrial development-as this was incompatible with feudal social property relations. Indeed, Bićanić himself acknowledges that Drašković was silent on the issue of serfdom, "the main question of Croatia's economic progress". ${ }^{75}$

His interpretation of the conflict between Hungarian and Croatian nationalism is more persuasive, even if some statements need to be qualified. Consistent with the arguments throughout his writings, Bićanić argued for the saliency of a world-systems perspective and outlined the contours of an argument that, if developed, would offer a way out of the stagism present in his interpretation of the transition to capitalism. Bićanić argues that the growing conflict between Hungary and Croatia from the 1830s onward should be related to the increased competition of peripheral producers on the world market. Especially Russian exports are seen as reducing prices on the world market and even outcompeting Croatian producers in the Adriatic harbors. This increased the competition on the internal market between Hungary and Croatia. ${ }^{76}$ Even more importantly from situating local developments in the context of the world-system, Bićanić pointed out that the Hungarian gentry did not have access to the world market. This precarious position led it to recognize the importance of the local market and ally itself with industrial interests. But this market had to be extended for any industrialization strategy to be feasible, which meant absorption of Croatia into Hungary. Furthermore, Croatia was the path to the world market. ${ }^{77}$ Bićanić also argued that jobs in the state apparatus were very important for the feudal class in decline. Thus, any Magyarization of Croatia was inimical to the class interests of Croatian gentry. ${ }^{78}$

\section{Towards world-systems analysis and uneven and combined development}

Unfortunately, these insights did not form the basis of a theoretically controlled account of the transition to capitalism because of the abiding stagism in Bićanić's argument, stagism that was a staple of scholarship in the period, both in the socialist bloc and the West. They therefore remain to be developed. However, there are still substantial obstacles in this regard. Although readers may consider the stagism of Bićanić's interpretation outdated,

74 István Széchenyi, Hitel (Credit), Pest 1830, 110, 83-87, 100, 104, 134, 231.

75 Bićanić, Počeci kapitalizma, 150-151.

76 Ibid., 146-147.

77 Isti, Doba manufakure, 326, 331.

78 Isti, Počeci kapitalizma, 153. 
they would be wrong to consider this perspective relegated to the dustbin of history. For stagism has survived in not significantly changed form in modernization theory that was present throughout the $20^{\text {th }}$ century Croatian historiography and is with us in this century too. Although uneven development under capitalism has clearly been a problem hardly unfamiliar to Croatian historians, the notion of the unevenness of development was substantially undermined, indeed at times cancelled, by explicit references to modernization theory. ${ }^{79}$ An interpretative synthesis of these disparate elements is necessarily difficult to sustain and can result in inconsistent argumentation. Despite sometimes very nuanced arguments typical of historians, these theoretical commitments necessarily came with a high price. And while one might quarrel with the ambiguities of these accounts, even these have been completely abandoned in a more recent account of $19^{\text {th }}$ century economic history by Vladimir Stipetić whose intellectual guide to the intricacies of Croatian history is... Walt Rostow. ${ }^{80}$ The difference here is that while Bićanić felt compelled to provide a framework to actually explain the transition to a capitalist economy, this is no longer considered necessary. In this sense, Bićanić remains unsurpassed.

A part of these problems could be potentially resolved by a greater engagement with WSA, already present in Habsburg historiography, ${ }_{1}^{81}$ where one finds a powerful framework for the examination of unevenness under capitalism. But while WSA may provide a useful framework for analyzing unevenness, it might fall short from illuminating the process of transition itself as well as state formation accompanying it. As I have already argued in relation to the political economy of $19^{\text {th }}$ century Monarchy, WSA seems ill-suited for explaining the peculiar state formation and transition to capitalism in the Monarchy due to the lack of historicization of different forms of politics as a result of the separation of the economic and the political, the explanation of state formation with the position in the capitalist world-system, and the neglect of articulation and combination between modes of production. Fortunately, a UCD perspective can address these shortcomings and account for both the transition to capitalism and state formation in Hungary by providing a perspective that takes into account both the specificity of the Hungarian social formation and the "world time" of the capitalist world-system. ${ }^{82}$ In the framework of UCD societies are analyzed in a multilinear and intersocietal perspective that goes beyond the societies conceived in the "ontological singular". The societies' reproduction is seen as necessarily dependent on other societies while the interaction of developmentally differentiated societies brings about social amalgamations in each society. Considering the uneven development between societies, the pressure of more developed ones ("the whip of external

79 Mirjana Gross, Prema hrvatskome građanskom društvu: društveni razvoj u civilnoj Hrvatskoj i Slavoniji šezdesetih i sedamdesetih godina 19. stoljeća [Towards Croatian Civil Society: Social Development in Civil Croatia and Slavonia in the 1860s and 1870s], Zagreb 1992; Igor Karaman, Hrvatska na pragu modernizacije (1750-1918) [Croatia on the Threshold of Modernization (1750-1918)], Zagreb 2000.

80 Stipetić, Dva stoljeća razvoja, 211-212.

81 Andrea Komlosy, Grenze und ungleiche regionale Entwicklung, Wien 2003; Isti, "Imperial Cohesion, National-Building and Regional Integration in the Habsburg Monarchy?", in: Nationalizing Empires, ed. Alexei Miller - Stefan Berger, Budapest 2014, 369-429; Klemens Kaps, Ungleiche Entwicklung in Central Europa. Galizien zwischen überregionaler Verflechtung und imperialer Politik (1772-1914), Vienna 2015.

82 Mladen Medved, "Trotsky or Wallerstein? Approaching the Habsburg Monarchy in the Nineteenth Century", East-Central Europe, 45/1, 2018, 39-62. 